155

Received: May 30, 2012

Accepted: November 172012
Macedonian Journal of Animal Science, Vol. 3, No. 2, pp. 91-96 (2013)

In print ISSN $1857-6907$

On line ISSN $1857-7709$

UDC: $599.324-116: 546.48$

Original scientific paper

\title{
TOXIC EFFECTS OF CADMIUM, BECAUSE OF CHRONIC EXPOSURE ON REPRODUCTION PARAMETERS OF CAVIA PORCELLUS FEMALES
}

\author{
Albana Munga, Dashamir Xhaxhiu, Dorjana Beqiraj, Jani Mavromati \\ Agricultural University of Tirana, Faculty of Veterinary Medicine, Tirana, Albania \\ albanamunga@yahoo.com
}

\begin{abstract}
Cadmium is a ubiquitous environmental pollutant of increasing worldwide concern. Cadmium accumulation occurs in various tissues and organs, with the most extensive accumulation in kidney cortex. This study analyzes some of cadmium effects on reproduction parameters of the females Cavia porcellus. Cadmium was applied by intraperitoneal injections in doses of $0.0005 \mathrm{mg} / \mathrm{kg} /$ day, $0.1148 \mathrm{mg} / \mathrm{kg} / \mathrm{day}$ and $0.2177 \mathrm{mg} / \mathrm{kg} / \mathrm{day}$ to the mature female Cavia porcellus. After 60 days, animals were killed and the samples of ovaries were prepared for optic microscope observations. The changes in the ovaries were compared with those of the healthy Cavia porcellus. The hormones secretion profile and cadmium accumulation were monitored weekly by analyzing blood samples. The increasing of Cadmium dose applied results in many pronounced histological damages in the ovary. Among the histological damages recorded were a high number of atretic follicula, arresting of their maturity, disruption of cell contacts, atrophy and disorganization of granulose cells, small corpus luteum with hemorrhagic processes. Increasing cadmium concentration reduces the secretion rate of estradiol $(r=-0.962)$, progesterone $(r=-0.83)$, FSH $(r=-0.962)$, and increases the secretion of testosterone $(r=0.98)$ and LH $(r=0.697)$.
\end{abstract}

Key words: cadmium; reproduction; ovary; gonadotropins; sexual steroides

\section{ТОКСИЧНИ ЕФЕКТИ НА КАДМИУМОТ ПОРАДИ ПОСТОЈАНА ИЗЛОЖЕНОСТ ВРЗ РЕПРОДУКТИВНИТЕ ПАРАМЕТРИТЕ КАЈ ЖЕНКИ ОД CAVIA РОRCELLUS}

\begin{abstract}
Кадмиумот е насекаде присутен загадувач на околината и претставува сѐ поголема опасност во светски размери. Кадмиумот се таложи во разни ткива и органи, но најголемо наталожување е во обвивката на бубрезите. Оваа студија ги анализира некои од ефектите на кадмиумот врз репродуктивните параметри кај женките од Cavia porcellus. Кадмиумот беше внесен директно во перитонитот преку инјекција во дози од $0.0005 \mathrm{mg} / \mathrm{kg} /$ ден, $0,1148 \mathrm{mg} / \mathrm{kg} /$ ден и $0,2177 \mathrm{mg} / \mathrm{kg} /$ ден во зрели женки од Cavia porcellus. По 60 дена животните беа убиени и примероците од овариумите беа подготвени за оптичка микроскопска опсервација. Промените во овариумите беа споредени со оние кај здрави единки од Cavia porcellus. Профилот на лачењето на хормоните и натрупувањето на кадмиумот беа следени секоја седмица со анализи на примероци од крв. Зголемената доза на внесен кадмиум покажа силно изразени хистолошки оштетувања во овариумот. Помеѓу забележаните хистолошки оштетувања беа зголемен број на незрели и дегенеративни фоликули, оштетувања во контактот на клетките, атрофија и дизорганизација на грануларните клетки, мал corpus luteum co хеморагични процеси, итн. Зголемената концентрација на кадмиум го намалува нивото на лачење на естрадиолот $(r=-0,962)$, прогестеронот $(r=-0,83)$, фоликуло-стимулирачкиот хормон $(r=-0,962)$, и го зголемува лачењето на тестостеронот $(r=0,98)$ и лутеинизирачкиот хормон - LH $(r=0,697)$.
\end{abstract}

Клучни зборови: кадмиум; репродукција; овариум; гонадотропни хормони; полови стероиди

\section{INTRODUCTION}

There are enough evidences to determine a connection between cadmium exposure and reproduction parameters. It is clear that cadmium is a toxic element for the reproductive system in many experimental works that have used histologic methods of research (Brzóska \& Moniuszko-Ja- koniuk (2005c, 2005d); Massányi et al. (1990); Massányi (1996)).

In mice, acute toxication with nearly lethal doses of cadmium can induce testicular atrophy and necrosis (Andersen et al. (1988); Borzelleca et al. (1989)) and also reduces fertility (Kotsonis \& Klaassen, (1978)). 
Generally, higher doses of cadmium are needed in female than in male, to induce a reproductive toxic response (Borzelleca et al. (1989)). A decrease in the percentage of fertilized female was reported in doses $61.32 \mathrm{mg} \mathrm{Cd} / \mathrm{kg} /$ day in 10 days (Machemer \& Lorke (1981)). During intermediate exposures significant prolongations of estral cycle were observed (Baranski \& Sitarek (1987)).

Some authors that used lower doses and longer time of exposure did not observe changes in the success of female reproduction (Petering et al. (1979); Sorell \& Graziano (1990)). Oral doses of $10 \mathrm{mg} \mathrm{Cd} / \mathrm{kg} /$ day for 9 weeks (6 weeks before gestation and 3 weeks during gestation) reduced significantly the number of copulated and pregnant femalec and the number of implanted and live fetus (Sutou et al. (1980)).

\section{MATERIALS AND METHODS}

The purpose of this study was to make an evaluation of the adverse effects of cadmium on ovary morphologic parameters and the changes in gonadotropin and sexual steroids secretion.

In this study female sexually mature Guinea pigs (Cavia porcellus) (body weight 400-600 g) were used. The animals were divided into three groups with 10 individuals each, and a control group of 10 individuals. Administration of the metal was made in three different doses, TDI (tolerably daily intake), $\mathrm{LD}_{50}-5 \%$ (in order to avoid the death till the end of the experiment) and an intermediate dose. The doses were injected intraperitoneally (in the lower abdominal quadrant) in form of $\mathrm{CdCl}_{2}$ aqueous solution. In this route the volume injected can reach $10-15 \mathrm{ml}$ for adult guinea pigs (Beynon \& Cooper (1991)). The doses applied were TDI 0,0005 mg Cd/kgbw/day (RIVM report $711701025,(2001)), \mathrm{LD}_{50}-5 \% 0.2177 \mathrm{mg}$ $\mathrm{Cd} / \mathrm{kgbw} /$ day and the intermediate dose $0.1148 \mathrm{mg}$ $\mathrm{Cd} / \mathrm{kgbw} /$ day.

Blood samples were collected every week via cardiac puncture (Beynon \& Cooper (1991)). After 60 days of experimentation the animals were sacrificed and during their dissection ovaries were extracted. All the samples were analyzed for cadmium content with the technique of Atomic Absorption Spectrometry (AAS). The spectrometer used was Varian Spectr-200 with limit of detection for cadmium $0,006 \mathrm{ppb}(\mu \mathrm{g} / \mathrm{l})$. Measurements of gonadotropins and sexual steroid hormones in serum using ELISA principle also were made. These measurements were made automatically in the Elecsys 2010 system with detections limits: estradiol $5.0 \mathrm{pg} / \mathrm{ml}$; progesterone $0.030 \mathrm{ng} / \mathrm{ml}$; testosterone $0.069 \mathrm{nmol} / \mathrm{l}$; LH $0.10 \mathrm{mIU} / \mathrm{ml}$ and $\mathrm{FSH}$ $0.10 \mathrm{mIU} / \mathrm{ml}$. These examinations were made in the laboratory of Analytic Chemistry, Institute of Food Safety and Veterinary, Tirana, Albania. Histologic preparations were realized with the standard method hemotoxilin-eosine, in the laboratory of Pathologic Anatomy near the Central Hospital "Mother Tereza".

\section{RESULTS AND DISCUSSION}

Examination of ovary histologic preparations in optic microscopy revealed great degenerative changes. In the following photographs some of adverse effects that cadmium has in the ovaries when administered in high doses are shown.

Figures 1 and 2 represent the normal morphology of the ovaries from the control group.

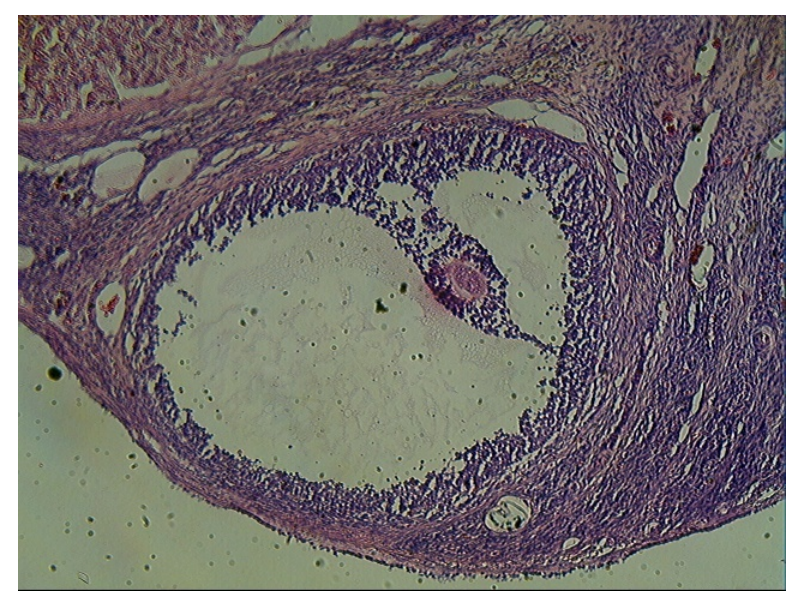

Figure 1. Follicle, control group $(10 \times)$

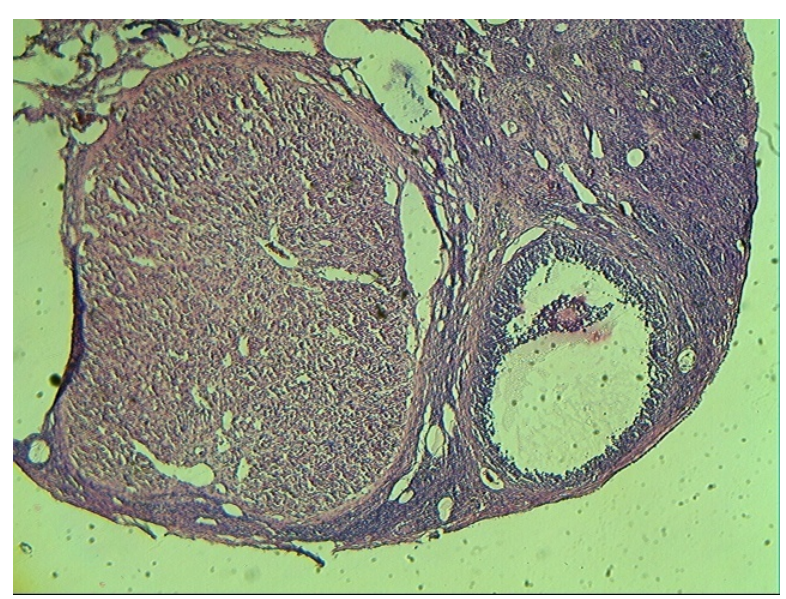

Figure 2. Follicle and corpus luteum, control group $(5 \times)$ 
In Figure 1, all the components of an antral follicle can be distinguished, the layers of theca interna and theca externa, the layers of granulosa cells are well organized as the cumulus cells and corona radiata. The big oocyte in maturation surrounded by zona pellucida is positioned in the center of corona radiate cells. A well-developed corpus luteum is also present. In the overall view there are present follicles in different stages of maturation, starting from primordial follicles to Graafian follicles.

Figures 3-7 show optic microscopy photos of ovaries from animals treated with different doses of cadmium.

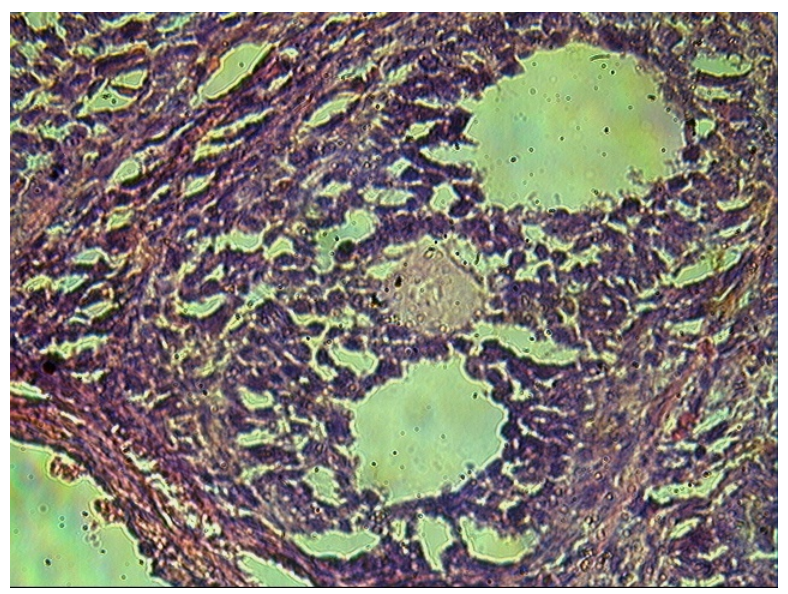

Figure 3. Follicle, TDI dose $(40 \times)$

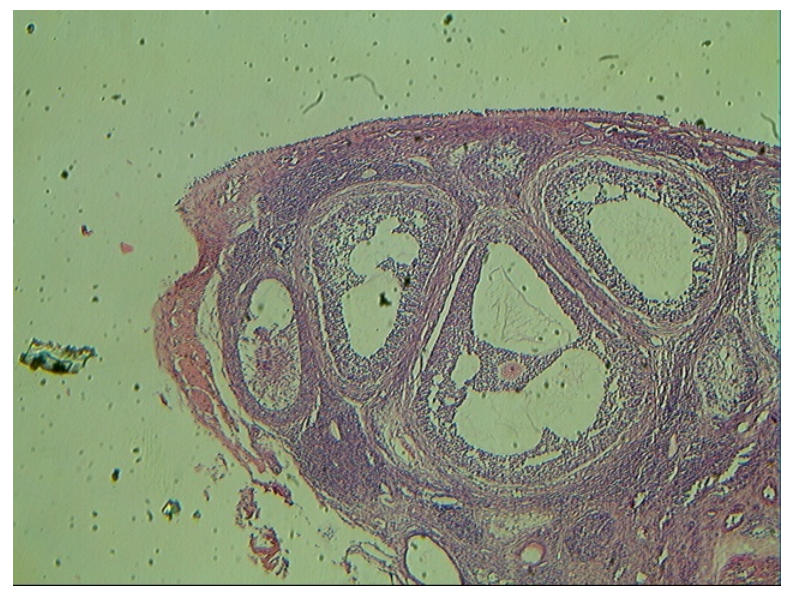

Figure 4. Follicles, intermediate dose $(5 \times)$

In the group treated with the TDI doses of cadmium, there can be seen no changes on histologic parameters of different groups of cells in the ovaries. The follicles contain the typical structures according to the stage of their maturation cycle and in the same ovary we can find follicles in different stages of maturation and the corpus $l u-$ teum.

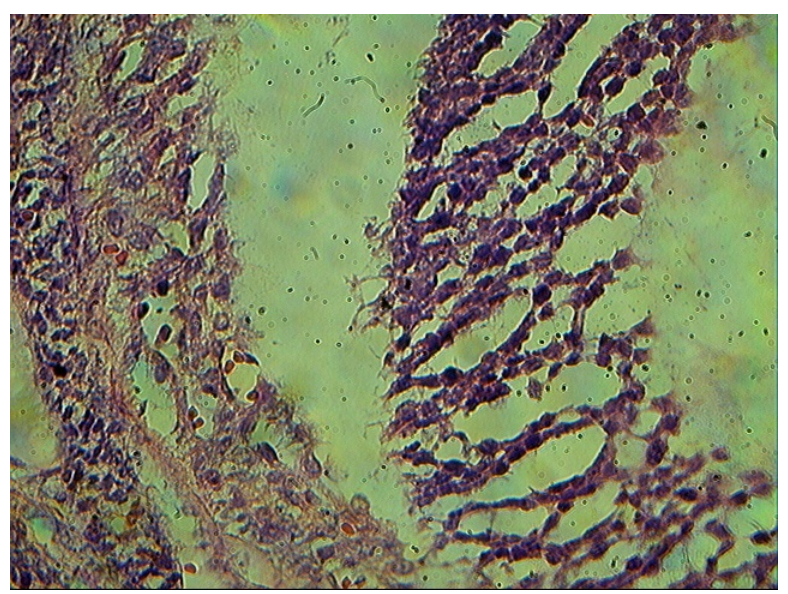

Figure 5. Follicle, intermediate dose $(40 \times)$

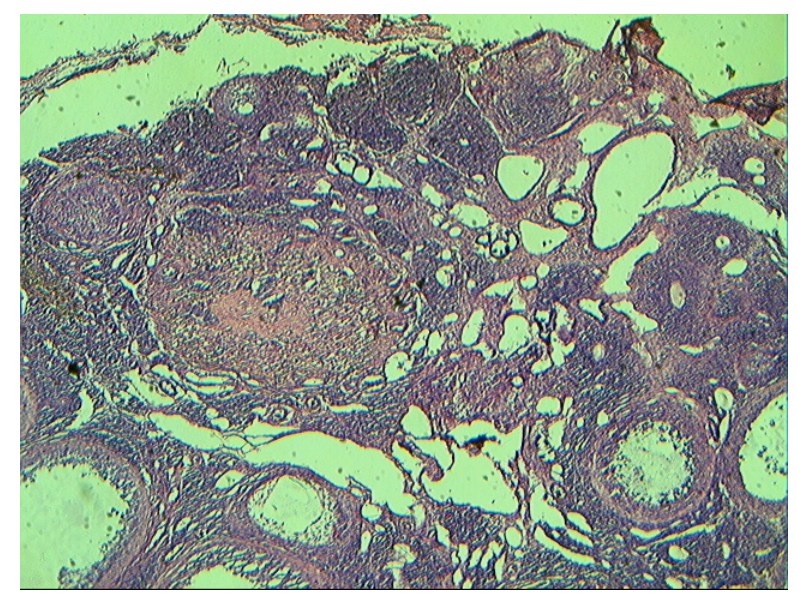

Figure 6. Follicles and corpus luteum, $\mathrm{LD}_{50}-5 \%$ dose $(5 \times)$

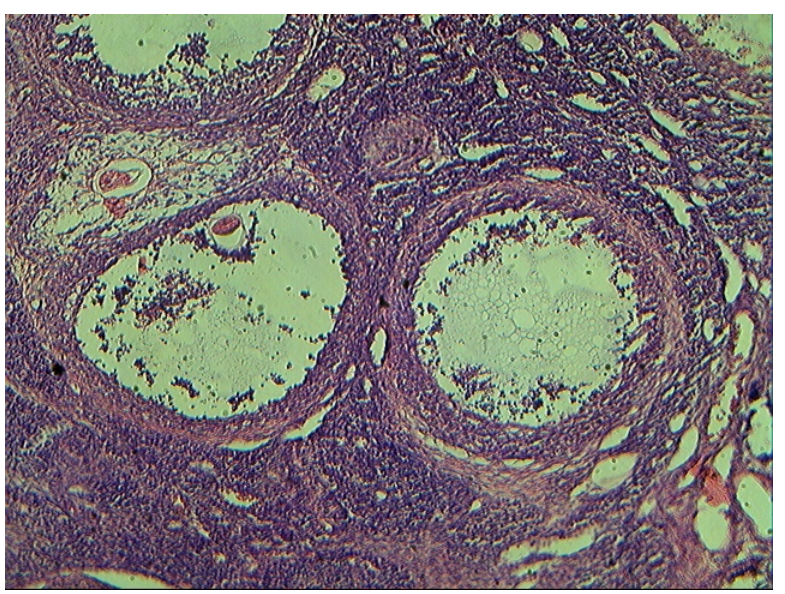

Figure 7. Follicles, $\mathrm{LD}_{50}-5 \%$ dose $(10 \times)$

In the groups treated with intermediate and $\mathrm{LD}_{50}-5 \%$ doses of cadmium the changes are apparent. There is a great increase of atretic follicles, a very small number of normal follicles in maturation process, disorganization of granulosa cells, fissures between the different layers of granulosa cells and between layers of granulosa and theca 
interna cells, small corpus luteum with hemorrhagic processes, blood vessels tending to hemor- rhage in the medullar region of the ovaries (LuboPalma et al. (2006)).

Table 1

Gonadotropin and sexual steroid hormones concentrations in females treated with cadmium

\begin{tabular}{|c|c|c|c|c|c|c|c|c|c|c|}
\hline Week & 0 & 1 & 2 & 3 & 4 & 5 & 6 & 7 & 8 & Week \\
\hline \multirow{4}{*}{$\begin{array}{c}\text { Estradiol } \\
(\mathrm{pg} / \mathrm{ml})\end{array}$} & 18.87 & 18.24 & 20.14 & 19.57 & 18.77 & 18.75 & 24.05 & 22.19 & 23.61 & Control \\
\hline & 22.18 & 21.46 & 20.03 & 18.53 & 20.17 & 20.20 & 19.41 & 18.45 & 21.52 & TDI \\
\hline & 20.08 & 19.38 & 14.26 & 14.55 & 12.27 & 12.61 & 12.64 & 10.32 & 11.48 & Int. dose \\
\hline & 19.89 & 14.16 & 9.40 & 8.28 & 6.96 & 5.38 & 6.80 & 5.19 & 5.10 & $\mathrm{LD}_{50^{-}}-5 \%$ \\
\hline \multirow{4}{*}{$\begin{array}{l}\text { Progesterone } \\
\qquad(\mathrm{ng} / \mathrm{ml})\end{array}$} & 4.165 & 2.083 & 3.157 & 3.569 & 2.844 & 4.921 & 3.483 & 2.877 & 4.028 & Control \\
\hline & 3.598 & 2.781 & 2.910 & 3.157 & 2.683 & 3.721 & 2.257 & 2.415 & 2.850 & TDI \\
\hline & 4.215 & 3.548 & 2.380 & 2.254 & 0.712 & 0.684 & 0.800 & 1.020 & 0.301 & Int. dose \\
\hline & 4.163 & 2.898 & 0.392 & 1.007 & 0.920 & 0.414 & 0.340 & 0.200 & 0.184 & $\mathrm{LD}_{50^{-}}-5 \%$ \\
\hline \multirow{4}{*}{$\begin{array}{l}\text { Testosterone } \\
(\mathrm{nmol} / \mathrm{l})\end{array}$} & 0.027 & 0.000 & 0.069 & 0.017 & 0.029 & 0.016 & 0.104 & 0.000 & 0.010 & Control \\
\hline & 0.025 & 0.010 & 0.012 & 0.081 & 0.058 & 0.082 & 0.038 & 0.127 & 0.056 & TDI \\
\hline & 0.047 & 0.027 & 0.015 & 0.135 & 0.178 & 0.222 & 0.180 & 0.273 & 0.285 & Int. dose \\
\hline & 0.035 & 0.030 & 0.084 & 0.191 & 0.199 & 0.316 & 0.551 & 0.460 & 0.486 & $\mathrm{LD}_{50^{-}}-5 \%$ \\
\hline \multirow{4}{*}{$\begin{array}{c}\mathrm{LH} \\
(\mathrm{mIU} / \mathrm{ml})\end{array}$} & 0.00 & 0.00 & 0.00 & 0.00 & 0.00 & 0.00 & 0.00 & 0.00 & 0.00 & Control \\
\hline & 0.00 & 0.00 & 0.00 & 0.00 & 0.00 & 0.00 & 0.00 & 0.00 & 0.00 & TDI \\
\hline & 0.00 & 0.00 & 0.00 & 0.10 & 0.24 & 0.27 & 0.31 & 0.30 & 0.28 & Int. dose \\
\hline & 0.00 & 0.00 & 0.23 & 0.20 & 0.19 & 0.21 & 0.21 & 0.19 & 0.20 & $\mathrm{LD}_{50^{-}}-5 \%$ \\
\hline \multirow{4}{*}{$\begin{array}{c}\text { FSH } \\
(\mathrm{mIU} / \mathrm{ml})\end{array}$} & 0.211 & 0.224 & 0.183 & 0.202 & 0.133 & 0.112 & 0.129 & 0.184 & 0.154 & Control \\
\hline & 0.223 & 0.216 & 0.175 & 0.192 & 0.141 & 0.158 & 0.134 & 0.170 & 0.168 & TDI \\
\hline & 0.195 & 0.190 & 0.181 & 0.179 & 0.145 & 0.076 & 0.070 & 0.051 & 0.058 & Int.dose \\
\hline & 0.232 & 0.206 & 0.134 & 0.027 & 0.000 & 0.000 & 0.000 & 0.000 & 0.000 & $\mathrm{LD}_{50^{-}}-5 \%$ \\
\hline
\end{tabular}

The graphic 1 shows considerable changes in estradiol secretion profile in the females treated with high doses of cadmium. In all cases the tendency is the reduction of estradiol secretion as the concentration of cadmium in the blood increases. In the group treated with TDI dose, there is little reduction of estradiol secretion and the statistical connection between the level of the hormone in the serum and the concentration of cadmium in blood is week and negative (Pearson's coefficient $r=$ 0.34 for $\alpha=0.05$ ). In the group treated with the intermediate and $\mathrm{LD}_{50}-5 \%$ dose the correlation is strong negative with values of Pearson's coefficient respectively: $\mathrm{r}=-0.88, \alpha=0.05$ and $\mathrm{r}=-0.86$, $\alpha=0.05$.

Regarding progesterone in groups treated with high doses of cadmium (graphic 2) the tendency is the same (continuous decrease) and the correlation is significantly negative (group Int.dose $r=-0.91, \alpha=0.05$ and group $L_{50}-5 \% r=-0.80$, $\alpha=0.05)$. In TDI group the levels of progesterone in serum are almost the same as those of control group with a non-significant correlation with the levels of cadmium in blood ( $\mathrm{r}=0.09, \alpha=0.05$ ). Thus, we can deduce that these low levels of cadmium in blood do not alter the secretion of progesterone.

Graphic 3 represents the testosterone secretion profile in the groups treated with cadmium. Except TDI group, that doesn't represent any significant alteration of testosterone levels $(r=0.28$, $\alpha=0.05$ ), the other two groups manifest significant increase of testosterone levels in serum over the weeks of experimentation and the correlation coefficients are very high (Int.dose group $r=0.94$, $\alpha=0.05$ and $\mathrm{LD}_{50}-5 \%$ group, $r=0.97, \alpha=0.05$ ). 
In groups treated with high doses of cadmium, as it can be seen from the graphic 4 , there is significant increase in LH secretion, while in the control group and TDI group the levels during all the period of experimentation resulted under the minimal detectible level of the apparatus used. In the intermediate and $\mathrm{LD}_{50}-5 \%$ group the increase is more pronounced from the first weeks of treatment and remains in high levels till the last week. Statistical connections between blood cadmium concentration and LH serum levels are determined by the following coefficients: Int.dose group $r=0.93$, $\alpha=0.05$ and $\mathrm{LD}_{50}-5 \%$ group $\mathrm{r}=0.67, \alpha=0.05$.

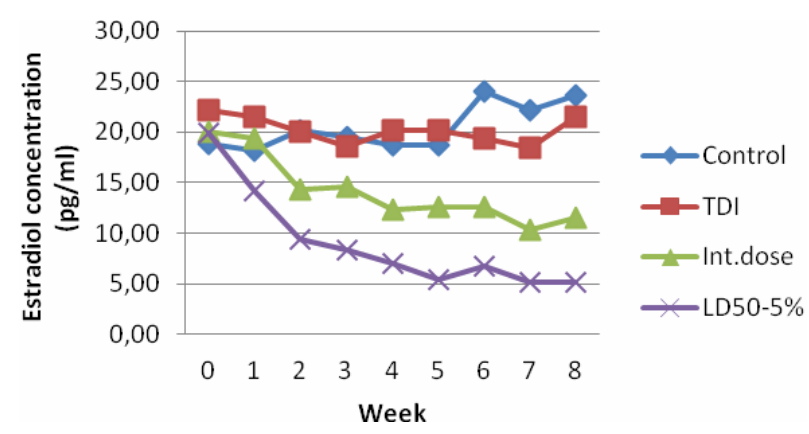

Graphic 1. Estradiol concentration in females treated with cadmium

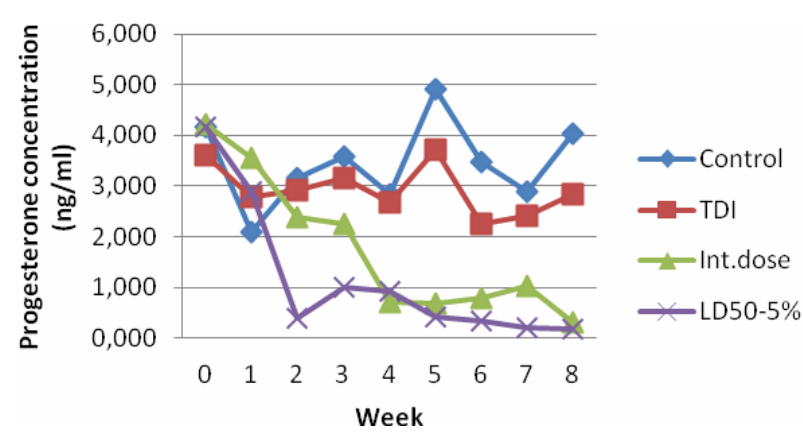

Graphic 2. Progesterone concentration in females treated with cadmium

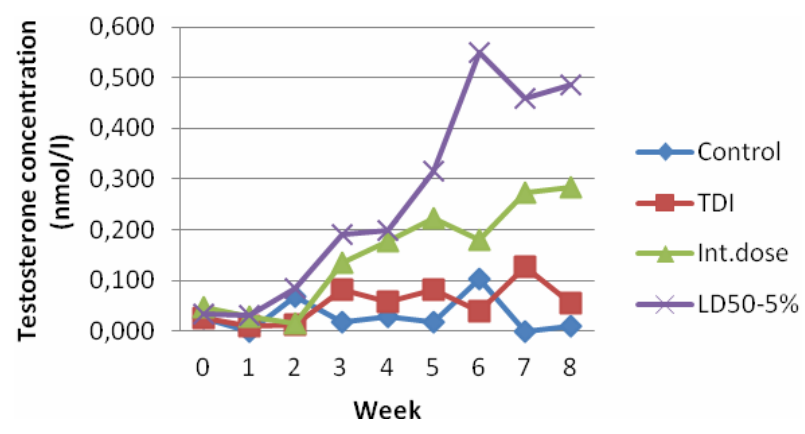

Graphic 3. Testosterone concentration in females treated with cadmium

The profile of FSH secretion in females treated with cadmium displayed in graphic 5, results almost the inverse of LH profile. Once again, in TDI group the deviation from the control group is insignificant and the Pearson's coefficient describing the statistical connection between FSH levels in serum and blood cadmium concentration is small $(\mathrm{r}=-0.22, \alpha=0.05)$. In both groups treated with high doses of cadmium there is a pronounced decrease of FSH secretion in blood and there is also a strong negative correlation between blood cadmium levels and FSH levels in serum (Int.dose group $\mathrm{r}=-0.97, \alpha=0.05$ and $\mathrm{LD}_{50}-5 \%$ group $r=-0.87, \alpha=0.05$ ).

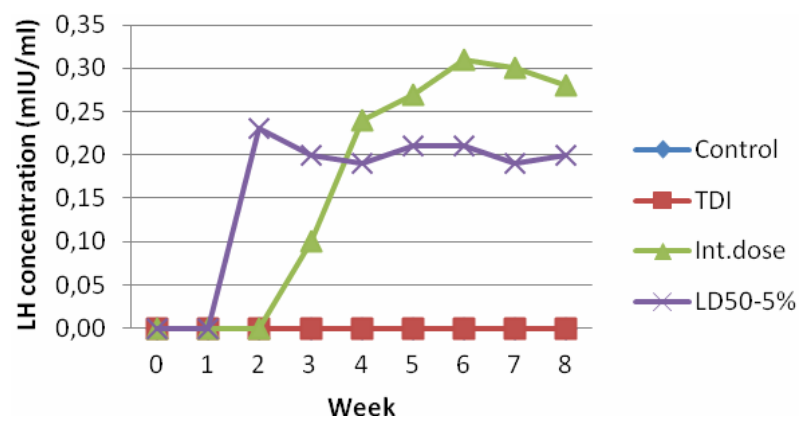

Graphic 4. LH concentration in females treated with cadmium

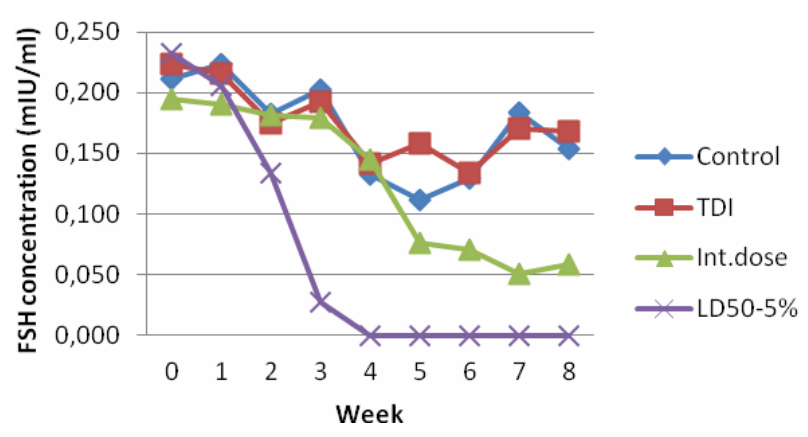

Graphic 5. FSH concentration in females treated with cadmium

Table 2 present the summary of all Pearson's coefficients that describe the statistical connections between the cadmium accumulation in blood according to the different doses applied during the 60 days period of manipulation with the animals and the profile of gonadotropins and sexual steroids secretion.

Different doses of cadmium can cause different effects in the secretion of gonadotropins and sexual steroid hormones. In TDI group the adverse effects seem to be lower than those in groups treated with higher doses of cadmium and also in different directions. This explains the contradictory results obtained by different authors, as the doses used or the concentration of the metal in blood from natural toxications were of different levels. 
Table 2

Pearson's correlation coefficients for hormone profile secretion in relation with blood cadmium levels

\begin{tabular}{|c|c|c|c|c|c|c|}
\hline Metal Hormone & Estradiol & Progesterone & Testosterone & LH & FSH & $\mathrm{m}$ \\
\hline \multirow{3}{*}{$\begin{array}{l}\text { O+ } \\
\text { 己 }\end{array}$} & -0.3360 & 0.0929 & 0.2793 & - & -0.2199 & TDI \\
\hline & -0.8843 & -0.9065 & 0.9406 & 0.9344 & -0.9751 & Int.dose \\
\hline & -0.8645 & -0.8042 & 0.9696 & 0.6687 & -0.8676 & $\mathrm{LD}_{50}-5 \%$ \\
\hline
\end{tabular}

\section{CONCLUSIONS}

- Gonads are not the main target for cadmium toxicity, but its adverse effects in the reproductive processes are considerable.

- In the dose considered as the tolerable daily intake, there are no significant changes in the morphologic structure of the ovaries.

- Histologic changes in the ovaries due to chronic toxication from cadmium are present as degenerative effects like hemorrhagic necrosis, atresia, disorganization of granulosa cells, detaching of granulosa and theca cells contacts, proliferation of fibrous tissue and arrest of follicles maturation process.

- Cadmium affects greatly the secretion of gonadotropins and sexual steroid hormones, either by reducing or increasing their secretion.

- High doses of cadmium have greater effects in the hormone secretion and this is proved by the high values of correlation coefficients (some of them negative and some positive).

- The effects of cadmium vary for different hormones secretion. The increase of cadmium concentration in blood is associated with the inhibition of estradiol, progesterone and FSH secretion, and with the increase of testosterone and LH secretion.

\section{REFERENCES}

[1] Andersen O., Nielsen J. B., Svendsen P. (1988): Oral cadmium chloride intoxication in mice: Effects of dose on tissue damage, intestinal absorption and relative organ distribution. Toxicology, 48, 225-236.

[2] Baranski B., Sitarek K. (1987): Effect of oral and inhalation exposure to cadmium on the oestrous cycle in rats. Toxicology Letters, 36:267-273.

[3] Beynon P. H., Cooper J. E. (1991): Manual of exotic pets, New edition, pp. 51-62.
[4] Borzelleca J. F., Clarke E. C., Condcie L. W. (1989): Short-term toxicity (1 and 10 days) of cadmium chloride in male and female rats: Gavage and drinking water. Journal of the American College of Toxicology, 8, 377404.

[5] Brzóska M. M., Moniuszko-Jakoniuk J. (2005): Effect of low-level lifetime exposure to cadmium on calciotropic hormones in aged female rats. Archives of Toxicology, 79 (11), 636-646.

[6] Brzóska M. M., Moniuszko-Jakoniuk J. (2005): Disorders in bone metabolism of female rats chronically exposed to cadmium. Toxicology and Applied Pharmacology, 202 (1), 68-83.

[7] Kotsonis F. N., Klaassen C. D. (1978): The relationship of metallothionein to the toxicity of cadmium after prolonged administration to rats. Toxicology and Applied Pharmacology, 46, 39-54.

[8] Lubo-Palma A., Nava-Leal C., Villasmil V., L., Montiel M., Simoes D., Faría C. (2006): Effects of cadmium on the ovarian parenchyma in Swiss albino mice. Investigacion clinica. Sep. 47 (3):219-31.

[9] Machemer L., Lorke D. (1981): Embryotoxic effect of cadmium on rats upon oral administration. Toxicology and Applied Pharmacology, 58, 438-443.

[10] Massányi L., Janovièová O., Bakitová L., Paška J., Toman R. (1991): Dangerous factors of environment affecting on spermatogenesis. Cadmium, (in Slovak). Polnohospodárstvo, 37, 830-848.

[11] Massányi P. (1996): The structural changes of the ovary, oviductus and uterus of female rabbits after cadmium administration (in Slovak). Slovak University of Agriculture, Nitra, 70.

[12] Petering H. G., Choudhury H., Stemmer K. I. (1979): Some effects of oral ingestion of cadmium on zinc, copper and iron metabolism. Environmental Health Perspectives, 28, 97-106.

[13] RIVM report 711701 025, 2001.

[14] Sorell T. L., Graziano J. H. (1990): Effect of oral cadmium exposure during pregnancy on maternal and fetal zinc metabolism in the rat. Toxicology and Applied Pharmacology, 102 (3), 537-545.

[15] Sutou S., Yamamoto K., Sendota H., Sugiyama M. (1980): Toxicity, fertility, teratogenicity, and dominant lethal tests in rats administered cadmium sub chronically. III. Fertility, teratogenicity, and dominant lethal tests. Ecotoxicology and Environmental Safety, 4, 51-56. 